\title{
Aluminium-doped Nickel Copper Ferrites for high-performance Supercapacitors
}

\author{
Bhamini BHUJUN*', Anandan S SHANMUGAM ${ }^{1}$, and Michelle T T Tan ${ }^{1}$
}

\begin{abstract}
A novel aluminium- doped nickel copper ferrite nanomaterial prepared via the sol-gel method is considered as potential electrode material for supercapacitors. The morphology, chemical composition and crystallinity have been investigated by scanning electron microscope, energy dispersive spectroscopy and $\mathrm{X}$ ray diffraction respectively. Electrochemical properties of the undoped and aluminium-doped nickel copper ferrite supercapacitor electrodes have been investigated by cyclic voltammetry and galvanostatic charge/ discharge measurements in $1 \mathrm{M} \mathrm{KOH}$. A specific capacitance of $412.5 \mathrm{Fg}^{-1}$ was obtained with $\mathrm{Al}_{0.2} \mathrm{Ni}_{0.4} \mathrm{Cu}_{0.4} \mathrm{Fe}_{2} \mathrm{O}_{4}$ at a current density of $1 \mathrm{Ag}^{-1}$ with energy density of $57.3 \mathrm{WhKg}^{-1}$.
\end{abstract}

Keywords_-Supercapacitor; Aluminium-doped; Ferrite; Electrochemical properties

\section{INTRODUCTION}

$\mathrm{T}$ HE rising markets for portable, small and light-weight electronic devices have brought about an ever-rising and pressing demand for environmentally friendly electrochemical energy storage systems, including batteries, fuel cells, capacitors and supercapacitors. Supercapacitors, also referred to as electrochemical capacitors, have been widely researched on due to their high power density, long cycle life (> 100000 cycles) and fast charging-discharging rates [1-3].

Over the recent years, spinel ferrites $\left(\mathrm{MFe}_{2} \mathrm{O}_{4}\right)$ have attracted considerable attention as supercapacitor electrodes because of their remarkable electrical properties, as well as the ability to exhibit various redox states [4-7]. $\mathrm{MnFe}_{2} \mathrm{O}_{4}$ and $\mathrm{NiFe}_{2} \mathrm{O}_{4}$ have been reported to demonstrate superior pseudocapacitance[8, 9].

Ferrites are often doped with metal ions in order to alter their electrical properties. Metals are usually chosen that have the desired effect at a low level in order to avoid reducing the electrical strength of the product. The addition of trivalent ions such as $\mathrm{Al}^{3+}$ in ferrite nanomaterials influences the electrical properties of the system and also increases resistivity which in turn lowers dielectric losses in supercapacitors $[10,11]$. The useful electrical properties of spinel ferrites are usually governed by the preparation conditions, chemical composition, sintering temperature, sintering time as well as doping additives[12]. Solution methods, in particular the sol-gel method, are employed because of its good stoichiometric control and the production of ultrafine particles in a relatively short processing time at lower temperatures.

Numerous studies on the effects of Al-substitution on the magnetic and electrical properties of different ferrites have been studied by various authors [13-15]. To the best of our knowledge, there are no works about the effect of Alsubstitution on the electrochemical properties of $\mathrm{Ni}-\mathrm{Cu}$ ferrites, prepared via the sol-gel method, in the literature. In view of this, we studied the effect of Al-substitution on the composition, microstructure, sizes and electrochemical properties of nano-crystalline $\mathrm{Al}_{\mathrm{x}} \mathrm{Ni}_{\mathrm{y}} \mathrm{Cu}_{\mathrm{z}} \mathrm{Fe}_{2} \mathrm{O}_{4} \quad(x+y+z=1)$, prepared through the citrate sol-gel method. The particle size and morphology were investigated by scanning electron microscopy, energy dispersive spectroscopy and X-Ray diffraction

\section{EXPERIMENTAL}

\section{A. Synthesis of nanomaterials}

The ferrite nanomaterials were synthesized via a facile solgel method as illustrated in Fig. 1.

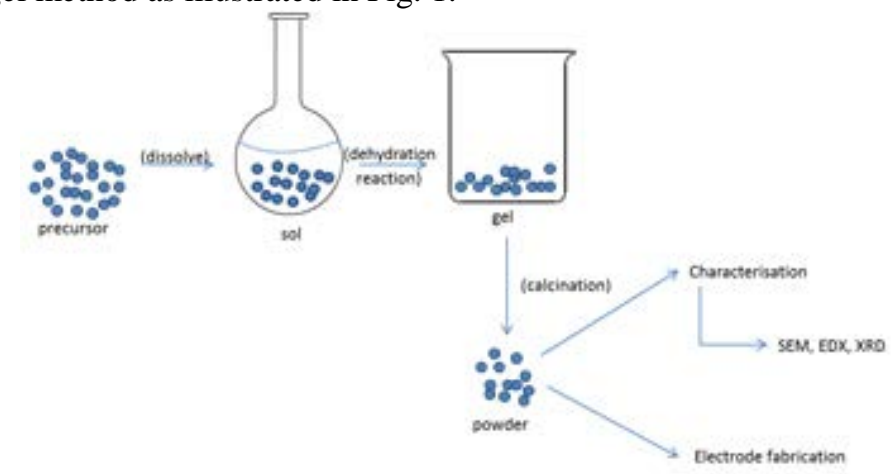

Fig.1 Schematic diagram of ferrite nanoparticles synthesised via solgel

Stoichiometric amounts of metal nitrates (nickel nitrate, copper nitrate, aluminium nitrate and ferric nitrate) were separately dissolved in $80 \mathrm{ml}$ of deionised water and $20 \mathrm{ml}$ of iso-propyl alcohol. Citric acid was then added to the prepared aqueous solution to chelate the cations in the solution[16]. During this procedure, the solution was continuously stirred using an ultrasonic sonicator (UP400S) at a frequency of 0.5 cycles and amplitude of $50 \%$ in order to ensure homogeneity in the solutions. The solution mixture was then slowly evaporated on a magnetic stirrer at a temperature of $125^{\circ} \mathrm{C}$ and speed of $150 \mathrm{rpm}$ until a viscous gel was formed. The thick slurry obtained was poured into ceramic boats for annealing in 
a tubular furnace. The dwell time and temperature set points of the furnace were increased at a ramping rate of $20^{\circ} \mathrm{C} / \mathrm{min}$ up till $600^{\circ} \mathrm{C}$ in order to remove the water, nitrate and carbon contents in the nanocomposite[16].

\section{B. Electrode fabrication}

The working electrodes for the supercapacitor were prepared using the following procedure: $70 \mathrm{wt} \%$ of the synthesised nanomaterial were mixed with 20 wt.\% of carbon black and $10 \mathrm{wt} . \%$ of polyvinyldifluoride (PVDF) prior to being dispersed in $N$-methyl-2-pyrrolidinone (NMP) to form a thick paste. The paste was the coated onto a single side of nitric acid treated aluminium sheet and dried at $70^{\circ} \mathrm{C}$ for 7 hours in a vacuum oven. The total weight of the active material in the electrode is usually $\sim 5 \mathrm{mg}$. For the fabrication of the carbon electrode, activated carbon was mixed with carbon black and PVDF in a mass ratio of 70:20:10 and a few drops of NMP.

\section{Sample characterisation}

The surface characteristics and elemental composition of the composites were analysed using a scanning electron microscope (SEM) (FEI Quanta-400 FESEM). The X-ray diffraction (XRD) patterns of the samples were observed by an X-ray diffractometer (XRD) (Philip XRD) operated at $33 \mathrm{~mA}$ and $45 \mathrm{kV}$ with $\mathrm{Cu} K \alpha$ radiation $(\lambda=1.54056 \AA)$ in the range of $10^{\circ}$ to $70^{\circ}$ with step size $0.03^{\circ}$.

\section{D.Electrochemical Measurements}

The asymmetrical supercapacitor cell was assembled in a two-electrode configuration for the galvanostatic charge/discharge analysis to an Arbin Instrument (BT-2000) using the MITS Pro 4.0512.12 software. Constant current densities ranging from 1 to $10 \mathrm{Ag}^{-1}$ have been employed for charging/discharging the cell in the voltage range $0-1 \mathrm{~V}$. The cyclic voltammetry was also studied in a two-electrode configuration using a VersaSTAT 3 (VE-400) electrochemical working station driven by the V3 studio version 1.0286 software. Cyclic voltammograms were recorded between 0 and $1 \mathrm{~V}$ w.r.t. reference electrode at a different scan rate (5$100 \mathrm{mVs}^{-1}$ ). A $1 \mathrm{M} \mathrm{KOH}$ aqueous solution was employed as electrolyte.

Based on the charge/discharge curve, the specific capacitance of the supercapacitor cell $\left(C_{\mathrm{sp}}, \mathrm{F} \mathrm{g}^{-1}\right)$ can be calculated according to the following equation[17]:

$C_{s p}=4 \times \frac{I}{(d v / d t) \times m}$

where $I(\mathrm{~A})$ is the discharge current, $d v / d t$ is the discharge slope after the IR drop, and $m$ (g) is the mass of active material in the electrode. The multiplier of 4 is to adjust the capacitance of two electrode cells to the capacitance of a single electrode.

\section{RESULTS AND DISCUSSION}

Fig. 2 shows the X-ray diffraction (XRD) pattern of aluminium-doped nickel copper ferrite particles with different Al contents (0.0 at\%, 0.2 at\%, 0.4 at\%, 0.6 at\%, 0.8 at\%) calcined at $600^{\circ} \mathrm{C}$. The XRD pattern analysed using X'Pert Highscore Plus software indicates that all the compositions exhibit single-phase cubic spinel structure with $\mathrm{Fd} 3 \mathrm{~m}$ space group with the presence of (220), (003), (311), (400), (422), (511) and (440) reflections in the diffractograms of the ferrite particles. The spectra show diffraction peaks of spinel ferrites only without any additional diffraction peaks such as $\mathrm{Al}_{\mathrm{x}} \mathrm{Ni}_{\mathrm{y}} \mathrm{Cu}_{\mathrm{z}} \mathrm{Fe}_{2} \mathrm{O}_{4}$. This might be due to the small quantity of aluminium which can substitute the tetrahedral or octahedral sites in the ferrite structure; therefore, there is no change of peak positions when doping ferrites with aluminium in this study. The XRD patterns correspond to similar observations made by Suwanboon et al. with aluminium doped nanoparticles[18]. The average crystallite size of the prepared ferrite particles were calculated from the width of the most intense diffraction peak (311) by means of the Debye-Scherrer equation[19]:

$$
t=\frac{0.9 \lambda}{\beta \cos \theta}
$$

where $t$ is the crystallite size, $\beta$ is the full width of the diffraction line at half maximum (FWHM) intensity measured in radians, $\lambda$ is the $\mathrm{X}$-ray wavelength of the $\mathrm{Cu} \mathrm{K \alpha}=1.54 \AA$, and $\theta$ refers to the Bragg's angle.

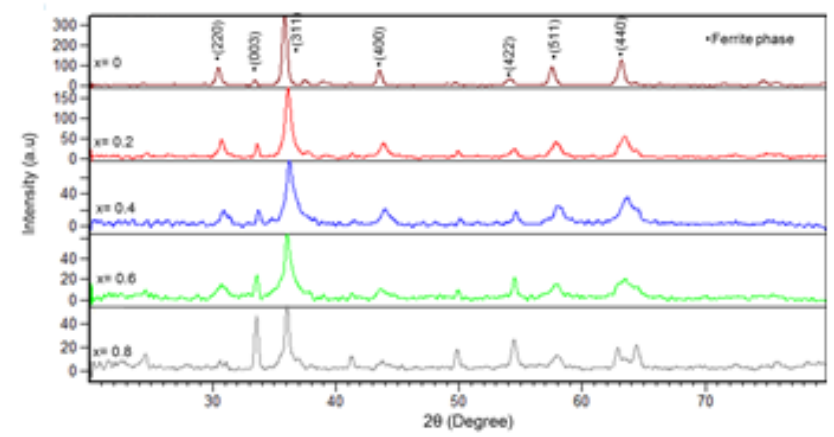

Fig.2 X- Ray diffraction pattern for undoped and aluminium-doped nickel copper ferrite nanomaterials

The variation of lattice parameter ' $a$ ' with the $\mathrm{Al}$ doping for various compositions is demonstrated in Fig. 3. It can be observed that an increase in $\mathrm{Al}$ content yields a decrease in the lattice parameter. The lattice constant values are in expected range with the lattice constants of spinel cubic ferrites [20,21]. The decrease in lattice constant with $\mathrm{Al}$ ion substitution can be explained on the basis of ionic radius, whereby the ionic radius of $\mathrm{Al}^{3+}$ ion $(0.535 \AA)$ is smaller than that of $\mathrm{Cu}^{2+}$ ion $(0.73 \AA)$ and $\mathrm{Ni}^{2+}$ ion $(0.69 \AA)$.

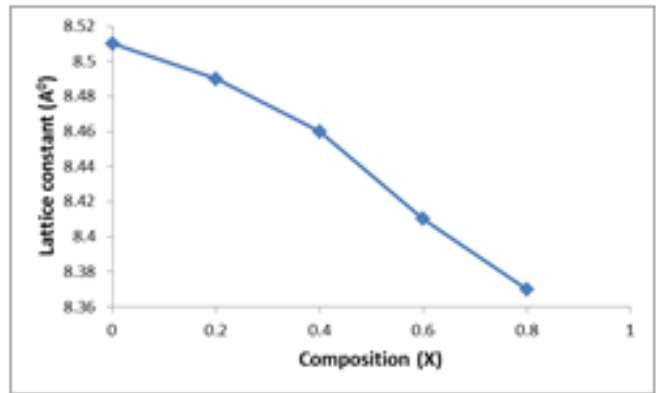

Fig.3 Variation of lattice parameter 'a' with increasing levels of aluminium doping

Fig. 4 illustrates the variation of crystallite size with $\mathrm{Al}$ doping. The crystallite size decreases with $\mathrm{Al}$ content up to a 
stoichiometry of 0.2 , showing a minimum value of $28.79 \mathrm{~nm}$, after which it increases slowly with increasing $\mathrm{Al}$ content. The average crystallite size of the ferrite nanomaterials with $\mathrm{Al}$ doping ranges between 28.7 and $60.6 \mathrm{~nm}$.

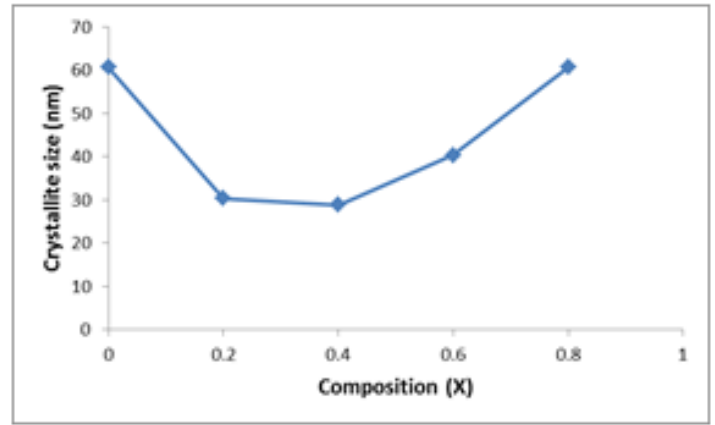

Fig.4 Variation of crystallite size with respect to aluminium doping

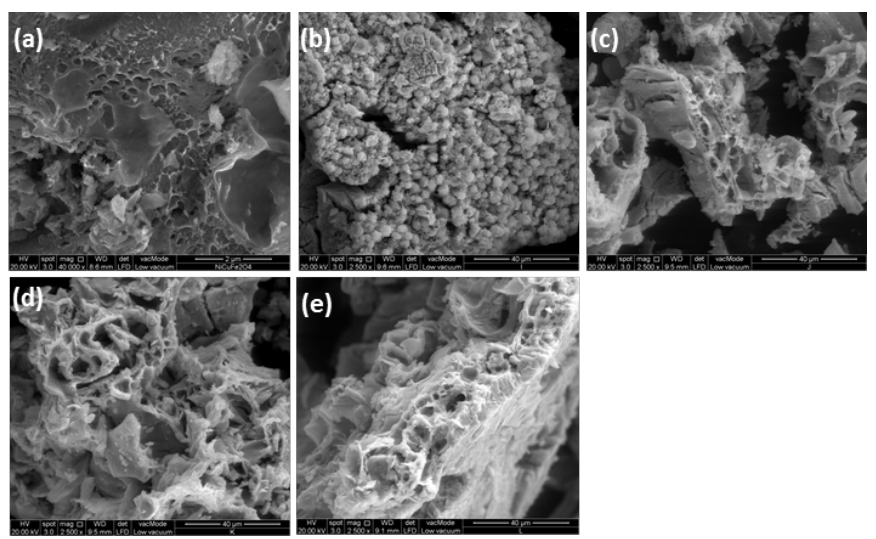

Fig.5 FESEM images of (a) NiCuF, (b) $\mathrm{Al}_{0.2} \mathrm{Ni}_{0.4} \mathrm{Cu}_{0.4} \mathrm{Fe}_{2} \mathrm{O}_{4}$, (c) $\mathrm{Al}_{0.4} \mathrm{Ni}_{0.2} \mathrm{Cu}_{0.2} \mathrm{Fe}_{2} \mathrm{O}_{4}$, (d) $\mathrm{Al}_{0.6} \mathrm{Ni}_{0.2} \mathrm{Cu}_{0.2} \mathrm{Fe}_{2} \mathrm{O}_{4}$ and

(e) $\mathrm{Al}_{0.8} \mathrm{Ni}_{0.1} \mathrm{Cu}_{0.1} \mathrm{Fe}_{2} \mathrm{O}_{4}$

The microstructure of the synthesised nanomaterials is observed using the SEM micrographs which is shown in Fig 5. (a-e). The interconnection of the clusters creates macropores which allow the transport of electrolyte, thereby creating large surface area for redox reactions[22]. In addition to this, nanopores have been observed on the surface of each cluster, with size varying from $10 \mathrm{~nm}$ to $100 \mathrm{~nm}$. These nanopores are useful since they provide easy path for ion movement at the electrode-electrolyte interface.

The chemical composition of the composites were analysed by an energy dispersive spectroscopy (EDS). The $\mathrm{C}, \mathrm{O}, \mathrm{Al}$, $\mathrm{Cu}, \mathrm{Co}, \mathrm{Ni}$ and Fe peaks in Fig. 6 in the EDS spectrum depict the presence of carbon, oxygen, aluminium, copper, cobalt, nickel and ferrite.
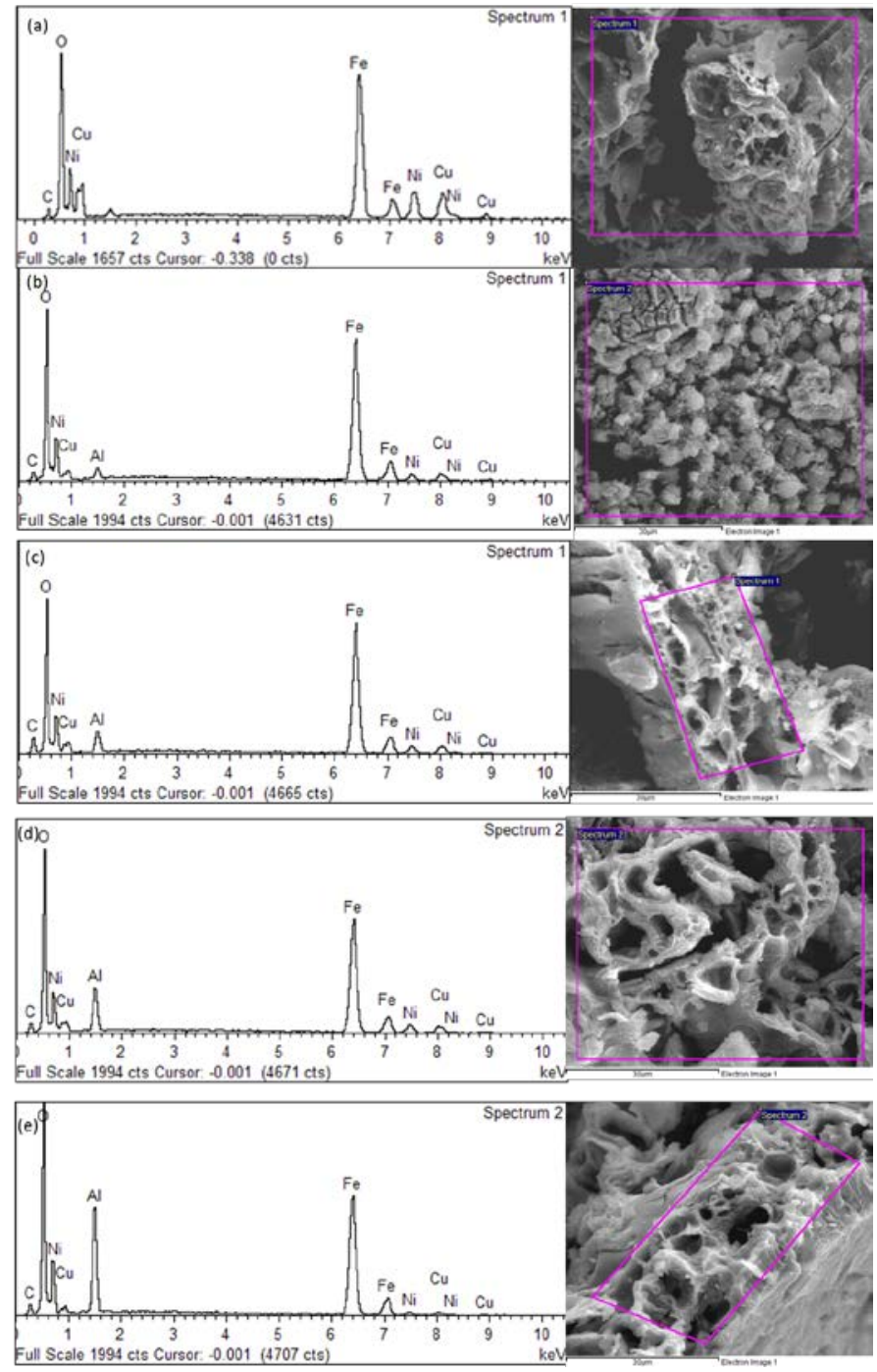

Fig.6 EDS spectrum of (a) NiCuF, (b) $\mathrm{Al}_{0.2} \mathrm{Ni}_{0.4} \mathrm{Cu}_{0.4} \mathrm{Fe}_{2} \mathrm{O}_{4}$, (c) $\mathrm{Al}_{0.4} \mathrm{Ni}_{0.2} \mathrm{Cu}_{0.2} \mathrm{Fe}_{2} \mathrm{O}_{4}$, (d) $\mathrm{Al}_{0.6} \mathrm{Ni}_{0.2} \mathrm{Cu}_{0.2} \mathrm{Fe}_{2} \mathrm{O}_{4}$ and

(e) $\mathrm{Al}_{0.8} \mathrm{Ni}_{0.1} \mathrm{Cu}_{0.1} \mathrm{Fe}_{2} \mathrm{O}_{4}$

\section{Electrochemical Properties}

Cyclic voltammetry plots of the undoped and doped nickel copper ferrite nanomaterials recorded in $1 \mathrm{M} \mathrm{KOH}$ electrolyte with a carbon reference electrode at a scan rate of $5 \mathrm{mVs}^{-1}$ are compared in Fig. 7. With the increase in aluminium doping, there is a noticeable increase in the current response as well as area of rectangle, suggesting that aluminium-doped nickel copper ferrite demonstrate higher specific capacitance as opposed to the undoped nickel copper ferrite nanomaterials.

The CVs of the $\mathrm{Al}_{0.2} \mathrm{Ni}_{0.4} \mathrm{Cu}_{0.4} \mathrm{Fe}_{2} \mathrm{O}_{4}$ electrode material at different scan rates $\left(5,10,50\right.$ and $\left.100 \mathrm{mVs}^{-1}\right)$ are shown in Fig. 8. At scan rates of 50 and $100 \mathrm{mVs}^{-1}$, the curves present an almost rectangular shape for charge/discharge process. At low rates, ions can reach both the inner and exterior surfaces of the nanomaterials, whereas at high rates, only the exterior surface is accessible [23].

At a scan rate of $5 \mathrm{mVs}^{-1}$, the supercapacitor electrodes of NiCuF, $\quad \mathrm{Al}_{0.2} \mathrm{Ni}_{0.4} \mathrm{Cu}_{0.4} \mathrm{Fe}_{2} \mathrm{O}_{4}, \quad \mathrm{Al}_{0.4} \mathrm{Ni}_{0.3} \mathrm{Cu}_{0.3} \mathrm{Fe}_{2} \mathrm{O}_{4}$, $\mathrm{Al}_{0.6} \mathrm{Ni}_{0.2} \mathrm{Cu}_{0.2} \mathrm{Fe}_{2} \mathrm{O}_{4}, \quad \mathrm{Al}_{0.8} \mathrm{Ni}_{0.1} \mathrm{Cu}_{0.1} \mathrm{Fe}_{2} \mathrm{O}_{4}$ deliver specific 
capacitances of $106.8 \mathrm{Fg}^{-1}, 272.6 \mathrm{Fg}^{-1}, 260 \mathrm{Fg}^{-1}, 330 \mathrm{Fg}^{-1}$, $367.4 \mathrm{Fg}^{-1}$ based on the active materials mass of two electrodes. These results suggest that the increased specific capacitance of the aluminium-doped ferrite nanomaterials originate from the mesoporous structure.

The effect of scan rate on specific capacitance is shown in Fig. 9. A noticeable decrease in the specific capacitances of all the synthesised nanomaterials is observed with an increase in scan rate. The ion-accessible surface area, or electrochemical reactive surface area, minimises with increasing scan rate, and in turn results in a reduced specific capacitance [23].

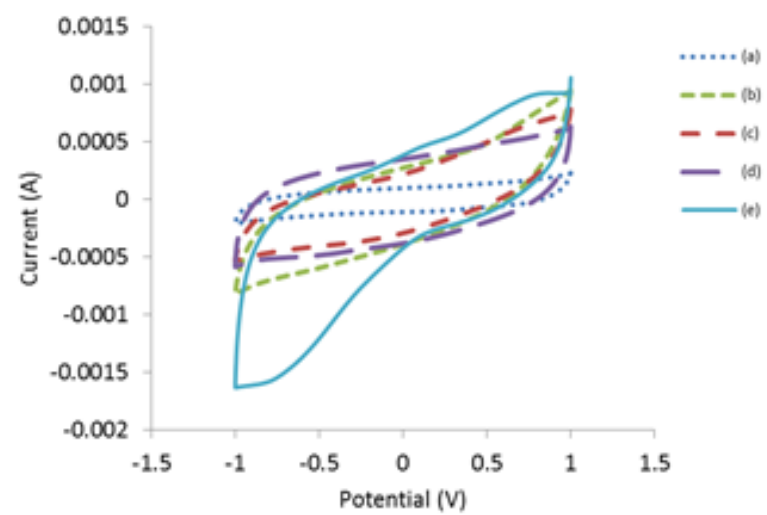

Fig.7 Cyclic voltammograms of (a) NiCuF, (b) $\mathrm{Al}_{0.2} \mathrm{Ni}_{0.4} \mathrm{Cu}_{0.4} \mathrm{Fe}_{2} \mathrm{O}_{4}$, (c) $\mathrm{Al}_{0.4} \mathrm{Ni}_{0.2} \mathrm{Cu}_{0.2} \mathrm{Fe}_{2} \mathrm{O}_{4}$, (d) $\mathrm{Al}_{0.6} \mathrm{Ni}_{0.2} \mathrm{Cu}_{0.2} \mathrm{Fe}_{2} \mathrm{O}_{4}$ and

(e) $\mathrm{Al}_{0.8} \mathrm{Ni}_{0.1} \mathrm{Cu}_{0.1} \mathrm{Fe}_{2} \mathrm{O}_{4}$ in $1 \mathrm{M} \mathrm{KOH}$ electrolyte at a scan rate of $5 \mathrm{mVs}^{-1}$.

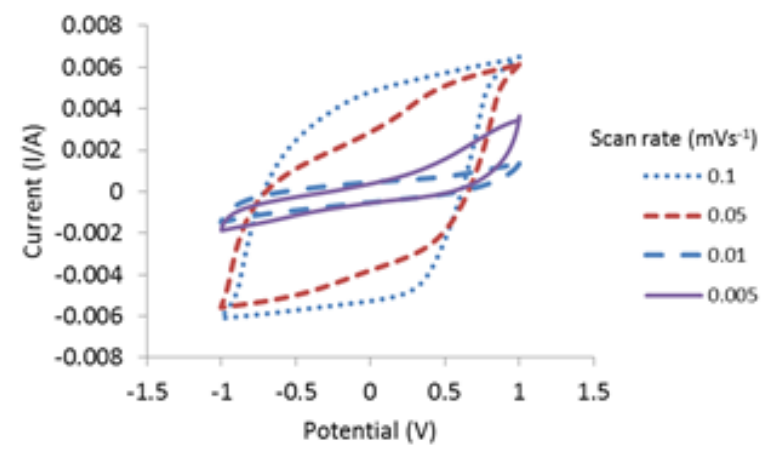

Fig.8 Cyclic voltammograms of $\mathrm{Al}_{0.2} \mathrm{Ni}_{0.4} \mathrm{Cu}_{0.4} \mathrm{Fe}_{2} \mathrm{O}_{4}$ at scan rates of $0.1,0.05,0.01$ and $0.005 \mathrm{mVs}^{-1}$

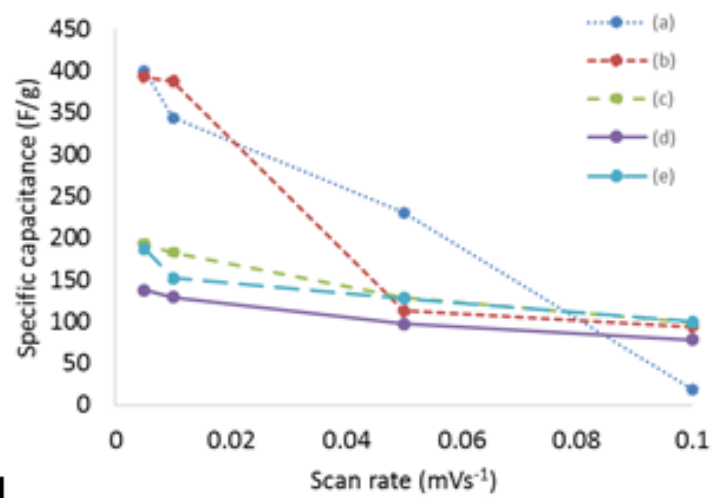

Fig. 9 Variation in specific capacitance of (a) NiCuF, (b) $\mathrm{Al}_{0.2} \mathrm{Ni}_{0.4} \mathrm{Cu}_{0.4} \mathrm{Fe}_{2} \mathrm{O}_{4}$, (c) $\mathrm{Al}_{0.4} \mathrm{Ni}_{0.2} \mathrm{Cu}_{0.2} \mathrm{Fe}_{2} \mathrm{O}_{4}$, (d) $\mathrm{Al}_{0.6} \mathrm{Ni}_{0.2} \mathrm{Cu}_{0.2} \mathrm{Fe}_{2} \mathrm{O}_{4}$ and (e) $\mathrm{Al}_{0.8} \mathrm{Ni}_{0.1} \mathrm{Cu}_{0.1} \mathrm{Fe}_{2} \mathrm{O}_{4}$ in $1 \mathrm{M} \mathrm{KOH}$ electrolyte with respect to scan rate
Galvanostatic charge-discharge analyses were established from the voltage response obtained from a series of charging and discharging currents to the supercapacitor.

Fig 10. illustrates typical charge-discharge curves of undoped and aluminium-doped NiCu ferrite nanocomposites at a current density of $1 \mathrm{Ag}^{-1}$ with voltage between 0 to $1 \mathrm{~V}$. The synthesised nanomaterials present a linear galvanostatic charge/discharge curve without obvious ohmic drop, indicating that they all possess a good capacitive behaviour under this loading current density. However, the specific capacitance of $\mathrm{Al}_{0.2} \mathrm{Ni}_{0.4} \mathrm{Cu}_{0.4} \mathrm{Fe}_{2} \mathrm{O}_{4}$ reaches $412.5 \mathrm{Fg}^{-1}$, much larger than that of $\mathrm{NiCuF}\left(274.3 \mathrm{Fg}^{-1}\right)$. The improved capacitance is attributed to an improvement in the electronic structure of $\mathrm{NiCuF}$.

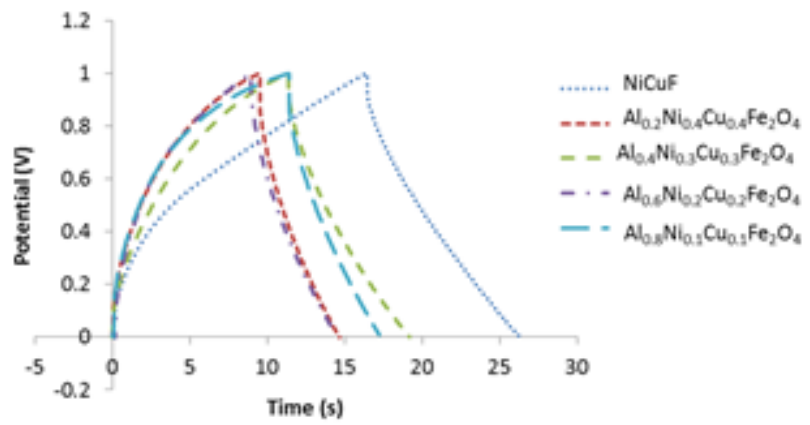

Fig.10 Galvanostatic charge/discharge curves of the synthesised nickel copper ferrite nanomaterials

The galvanostatic charge/discharge curves of $\mathrm{Al}_{0.2} \mathrm{Ni}_{0.4} \mathrm{Cu}_{0.4} \mathrm{Fe}_{2} \mathrm{O}_{4}$ at various current densities are depicted in Fig.11. At a high current density $\left(10 \mathrm{Ag}^{-1}\right)$, the specific capacitance of $\mathrm{Al}_{0.2} \mathrm{Ni}_{0.4} \mathrm{Cu}_{0.4} \mathrm{Fe}_{2} \mathrm{O}_{4}$ is found to be $249.3 \mathrm{Fg}^{-1}$ which does not differ much from the specific capacitance value at $2 \mathrm{Ag}^{-1}$. The unchanged specific capacitance can be attributed to the quite small equivalent series resistance (ESR) for the ionic diffusion at a high speed[24].

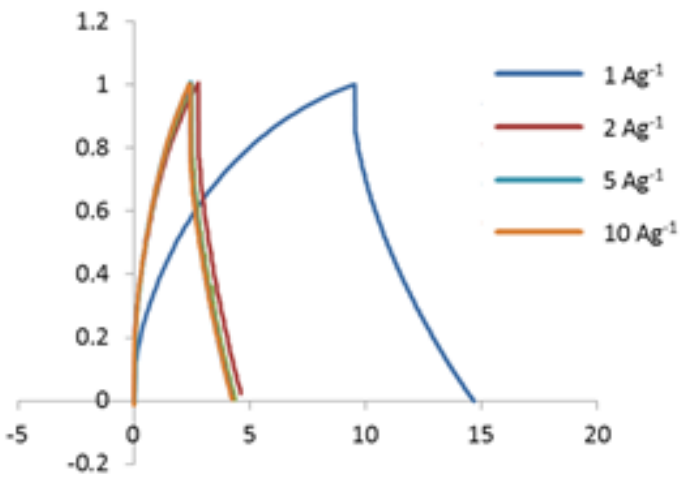

Fig.11 Galvanostatic charge/discharge curves of $\mathrm{Al}_{0.2} \mathrm{Ni}_{0.4} \mathrm{Cu}_{0.4} \mathrm{Fe}_{2} \mathrm{O}_{4}$ in $1 \mathrm{M} \mathrm{KOH}$ electrolyte at current densities of $1,2,5$ and $10 \mathrm{Ag}^{-1}$.

The specific capacitances obtained from the chargedischarge curves at a current density of $1 \mathrm{Ag}^{-1}$ (Table 1) are in accord to those obtained from the $\mathrm{CV}$ curves. The average energy density $(E)$ of the electrochemical capacitors were calculated using the following equations[25] :

$$
E=\frac{1000 C_{s} \times \Delta V^{2}}{2 \times 3600}
$$


where $E$ corresponds to the energy density of the electrode $\left(W_{k g}{ }^{-1}\right), C_{s}$ is the specific capacitance of the supercapacitor $\left(\mathrm{Fg}^{-1}\right)$, and $\Delta V$ indicates the voltage range for one sweep segment.

Table 1 displays the energy densities of the doped and undoped ferrite supercapacitor electrodes calculated from the galvanostatic charge-discharge curves at a current density of 1 $\mathrm{Ag}^{-1}$.

TABLE I

SPECIFIC CAPACITANCES AND ENERGY DENSITIES OF THE SYNTHESISED FERRITE SUPERCACITORS IN 1M KOH AT A CURRENT DENSITY OF $1 \mathrm{AG}^{-1}$

\begin{tabular}{|l|l|l|}
\hline Electrode material & $\begin{array}{l}\text { Specific capacitance } \\
\left(\mathbf{C}_{\mathbf{s}} / \mathbf{F g}^{-\mathbf{1}} \mathbf{)}\right.\end{array}$ & $\begin{array}{l}\text { Energy density } \\
\left(\mathbf{W h k g}^{-\mathbf{1}} \mathbf{)}\right.\end{array}$ \\
\hline $\mathrm{NiCuF}$ & 274.25 & 34.3 \\
\hline $\mathrm{Al}_{0.2} \mathrm{Ni}_{0.4} \mathrm{Cu}_{0.4} \mathrm{Fe}_{2} \mathrm{O}_{4}$ & 412.5 & 57.3 \\
\hline $\mathrm{Al}_{0.4} \mathrm{Ni}_{0.3} \mathrm{Cu}_{0.3} \mathrm{Fe}_{2} \mathrm{O}_{4}$ & 295 & 40.9 \\
\hline $\mathrm{Al}_{0.6} \mathrm{Ni}_{0.2} \mathrm{Cu}_{0.2} \mathrm{Fe}_{2} \mathrm{O}_{4}$ & 410 & 56.9 \\
\hline $\mathrm{Al}_{0.8} \mathrm{Ni}_{0.1} \mathrm{Cu}_{0.1} \mathrm{Fe}_{2} \mathrm{O}_{4}$ & 267.5 & 37.2 \\
\hline
\end{tabular}

\section{CONCLUSION}

To summarise, we have synthesised aluminium-doped nickel copper ferrite nanomaterials as potential supercapacitor electrodes. To the best of our knowledge, it is the first time that aluminium doping has been introduced in ferrite nanomaterials to enhance their electrochemical properties. A high specific capacitance of $412.5 \mathrm{Fg}^{-1}$ was obtained with $\mathrm{Al}_{0.2} \mathrm{Ni}_{0.4} \mathrm{Cu}_{0.4} \mathrm{Fe}_{2} \mathrm{O}_{4}$ at a current density of $1 \mathrm{Ag}^{-1}$. An energy density of $57.3 \mathrm{WhKg}^{-1}$ was recorded with $\mathrm{Al}_{0.2} \mathrm{Ni}_{0.4} \mathrm{Cu}_{0.4} \mathrm{Fe}_{2} \mathrm{O}_{4}$ whereas with undoped $\mathrm{NiCuF}$, an energy density of 34.3 $\mathrm{WhKg}^{-1}$ was obtained. The advantages of aluminium doping in this nanomaterial are: (1) easy and fast synthesis; (2) excellent performance (high specific capacitance). All these characteristics testify that the aluminium doped nickel copper ferrite nanomaterial may be a promising candidate for supercapacitors.

\section{REFERENCES}

[1] Simon, P. and Y. Gogotsi, Materials for electrochemical capacitors. Nat Mater, 2008. 7(11): p. 845-854. http://dx.doi.org/10.1038/nmat2297

[2] Zhang, L.L. and X.S. Zhao, Carbon-based materials as supercapacitor electrodes. Chemical Society Reviews, 2009. 38(9): p. 2520-2531. http://dx.doi.org/10.1039/b813846j

[3] Nyholm, L., et al., Toward flexible polymer and paper-based energy storage devices. Advanced Materials, 2011. 23(33): p. 3751-3769. http://dx.doi.org/10.1002/adma.201004134

[4] Gunjakar, J.L., et al., Chemical synthesis of spinel nickel ferrite (NiFe2O4) nano-sheets. Applied Surface Science, 2008. 254(18): p. 5844-5848. http://dx.doi.org/10.1016/j.apsusc.2008.03.065

[5] Sun, S., et al., Monodisperse MFe2O4 (M = Fe, Co, Mn) Nanoparticles. Journal of the American Chemical Society, 2004. 126(1): p. 273-279. http://dx.doi.org/10.1021/ja0380852

[6] Deng, D.H., et al., Fabrication of cobalt ferrite nanostructures and comparison of their electrochemical properties. Crystal Research and Technology, 2012. 47(10): p. 1032-1038. http://dx.doi.org/10.1002/crat.201200161

[7] Lokhande, C.D., D.P. Dubal, and O.-S. Joo, Metal oxide thin film based supercapacitors. Current Applied Physics, 2011. 11(3): p. 255-270. http://dx.doi.org/10.1016/j.cap.2010.12.001

[8] Kuo, S.-L. and N.-L. Wu, Electrochemical Capacitor of MnFe2O4 with $\mathrm{NaCl}$ Electrolyte. Electrochemical and Solid-State Letters, 2005. 8(10): p. A495-A499. http://dx.doi.org/10.1149/1.2008847

[9] Sen, P. and A. De, Electrochemical performances of poly(3,4ethylenedioxythiophene)-NiFe2O4 nanocomposite as electrode for supercapacitor. Electrochimica Acta, 2010. 55(16): p. 4677-4684. http://dx.doi.org/10.1016/j.electacta.2010.03.077

[10] Tsushima, T., Magnetic Properties of Ferrite-Chromite Series of Nickel and Cobalt. Journal of the Physical Society of Japan, 1963. 18(8): p. 1162-1166. http://dx.doi.org/10.1143/JPSJ.18.1162

[11] Bhosale, A.G. and B.K. Chougule, X-ray, infrared and magnetic studies of Al-substituted Ni ferrites. Materials Chemistry and Physics, 2006. 97(2-3): p. 273-276. http://dx.doi.org/10.1016/j.matchemphys.2005.08.022

[12] Kolekar, C.B., et al., Effect of Gd3+ substitution on dielectric behaviour of copper-cadmium ferrites. Journal of Materials Science, 1995. 30(22): p. 5784-5788. http://dx.doi.org/10.1007/BF00356721

[13] Fu, Y.-P., et al., Microwave-induced combustion synthesis of $\mathrm{Li0} .5 \mathrm{Fe} 2.5-\mathrm{xMxO} 4(\mathrm{M}=\mathrm{Al}, \mathrm{Cr}, \mathrm{Mn})$ powder and their characterization. Journal of Alloys and Compounds, 2005. 395(1-2): p. 272-276.

http://dx.doi.org/10.1016/j.jallcom.2004.11.048

[14] Sankpal, A.M., et al., Magnetization studies on aluminium and chromium substituted $\mathrm{Ni}-\mathrm{Zn}$ ferrites. Journal of Magnetism and Magnetic Materials, 1998. 186(3): p. 349-356.

http://dx.doi.org/10.1016/S0304-8853(97)01156-6

[15] Baldha, G.J., et al., Study of cation distribution and macro-magnetic properties of magnesium and aluminum co-substituted lithium ferrite. Materials Letters, 2002. 53(4-5): p. 233-237. http://dx.doi.org/10.1016/S0167-577X(01)00482-7

[16] Haijun, Z., Y. Xi, and Z. Liangying, The preparation and microwave properties of Ba3ZnZCo2-ZFe24O41 ferrite by citrate sol-gel process. Materials Science and Engineering: B, 2001. 84(3): p. 252-257. http://dx.doi.org/10.1016/S0921-5107(01)00629-8

[17] Hulicova-Jurcakova, D., et al., Highly Stable Performance of Supercapacitors from Phosphorus-Enriched Carbons. Journal of the American Chemical Society, 2009. 131(14): p. 5026-5027. http://dx.doi.org/10.1021/ja809265m

[18] Suwanboon, S., et al., Structural and optical properties of undoped and aluminium doped zinc oxide nanoparticles via precipitation method at low temperature. Journal of Alloys and Compounds, 2008. 462(1-2): p. 335-339.

http://dx.doi.org/10.1016/j.jallcom.2007.08.048

[19] H.E. Schaefer, H.K., H. Kronmuller, R. Wurschum,, Nanostruct. Mater, 1995. 6(533)

[20] Chandra, P., J. Mater. Sci. Lett., 1987. 6: p. 651-652. http://dx.doi.org/10.1007/BF01770914

[21] Elkony, D., Egypt J. Sol, 2004. 27(2): p. 285-296.

[22] Jiang, H., et al., Hierarchical self-assembly of ultrathin nickel hydroxide nanoflakes for high-performance supercapacitors. Journal of Materials Chemistry, 2011. 21(11): p. 3818-3823. http://dx.doi.org/10.1039/c0jm03830j

[23] Su, B.L., C. Sanchez, and X.Y. Yang, Hierarchically Structured Porous Materials: From Nanoscience to Catalysis, Separation, Optics, Energy, and Life Science. 2012: Wiley.

[24] Li, L., et al., A doped activated carbon prepared from polyaniline for high performance supercapacitors. Journal of Power Sources, 2010. 195(5): p. 1516-1521. http://dx.doi.org/10.1016/j.jpowsour.2009.09.016

[25] Fan, Z., et al., Asymmetric Supercapacitors Based on Graphene/MnO2 and Activated Carbon Nanofiber Electrodes with High Power and Energy Density. Advanced Functional Materials, 2011. 21(12): p. 23662375.

http://dx.doi.org/10.1002/adfm.201100058 